\title{
Immune Thrombocytopenia Induced by Nivolumab in a Metastatic Non-Small Cell Lung Cancer Patient
}

\author{
Yusuf Karakas $^{a} \quad$ Deniz Yuce $^{\mathrm{b}} \quad$ Saadettin Kılıckap $^{\mathrm{b}}$ \\ ${ }^{a}$ Department of Medical Oncology, Hacettepe University Cancer Institute, Ankara, Turkey; \\ ${ }^{b}$ Department of Preventive Oncology, Hacettepe University Cancer Institute, Ankara, Turkey
}

\section{Keywords \\ Nivolumab - Immune thrombocytopenia . Immune-related adverse effect}

Nivolumab is a fully human immunoglobulin G4 monoclonal antibody which selectively inhibits programmed cell death-1 (PD-1) activity by binding to the $\mathrm{PD}-1$ receptor. $\mathrm{PD}-1$ receptor inhibition regulates $\mathrm{T}$-cell activation and proliferation.

Based on randomized trial data, nivolumab demonstrates an overall survival benefit compared with docetaxel in advanced nonsmall cell lung cancer (NSCLC) [1].

Nivolumab is now approved for metastatic NSCLC which has progressed after platinum-based chemotherapy or epidermal growth factor receptor(EGFR)- / anaplastic lymphoma kinase (ALK)-directed therapy.

Recent studies have shown that autoimmune-like syndromes can occur in patients receiving immune checkpoint inhibitors. Toxicities with PD-1 antibodies include skin-related events, colitis, hepatitis, endocrinopathies, neurologic events, and rarely hematologic events [2]. Hematologic immune-related adverse events (irAEs) were previously defined in melanoma patients treated with ipilimumab [3, 4], and nivolumab was reported to have exacerbated immune thrombocytopenia in a patient with NSCLC [5]. Herein, we report the first case of de-novo immune thrombocytopenia caused by nivolumab in NSCLC.

A 78-year-old man was referred to us with a left lung pleural mass. His medical history included 12 pack-years of smoking, and he was previously diagnosed with chronic obstructive pulmonary disease. He also had been treated for early-stage lymphoma in 2011 for which he had been followed for 5 years while in remission. A computed tomography of the chest demonstrated a left upper lobe with an irregular shaped mass measuring $17 \times 26 \mathrm{~mm}$ which had caused the destruction of the third rib. Positron emission tomogra-

\section{KARGER}

(c) 2017 S. Karger GmbH, Freiburg phy and cranial magnetic resonance imaging were performed for staging. The tumor was shown to have invaded the third rib, the pleural nodules, and the left hilar region, revealing cT4N1M1a disease. The tumor did not have an EGFR mutation or ALK translocation. The patient progressed after 3 cycles of paclitaxel and carboplatin and was given single-agent nivolumab $(3 \mathrm{mg} / \mathrm{kg}$, every 2 weeks). Pre-treatment platelet counts were normal. At the end of the 6th nivolumab infusion, the platelet count suddenly decreased. Nivolumab was subsequently withheld, but the platelets continued to drop to a nadir of $5,000 / \mathrm{mm}^{3}$. However, leukocyte and hemoglobin levels were normal. The patient had no severe bleeding, bruising, or petechiae during this period. A peripheral smear demonstrated reduced platelets, a few giant platelets, and normal leukocytes/erythrocytes. Platelet transfusions were given for 4 weeks. After 5 weeks of persistent thrombocytopenia, a bone marrow biopsy was performed. This revealed hypercellularity and an increased rate of megakaryocytes. Hence, the patient had isolated thrombocytopenia in the absence of other causes and was diag-

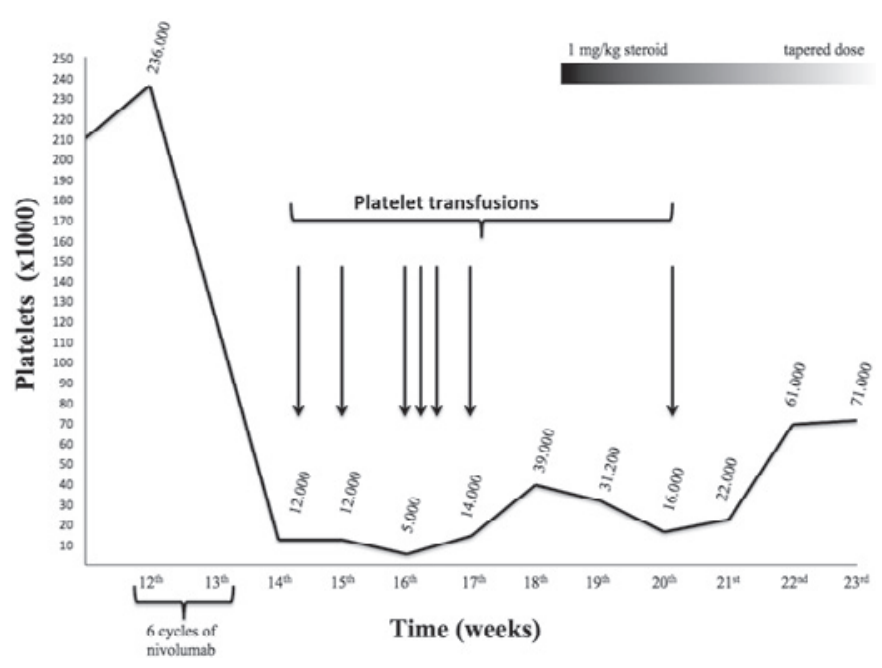

Fig. 1. Platelet count during nivolumab treatment 
nosed with immune thrombocytopenia. Treatment with $1 \mathrm{mg} / \mathrm{kg}$ of steroids was started [6]. 2 months later, a sufficient level of platelets had been achieved $\left(71,000 / \mathrm{mm}^{3}\right)$ (fig. 1); however, the platelet count did not return to normal with steroid treatment. Nevertheless, due to the platelet level being sufficient, no additional immunosuppressive treatment was given. Unfortunately, the patient died 6 months later due to lung cancer progression.

De-novo hematologic irAEs are a rare occurrence with immune checkpoint inhibitors. Also, immune thrombocytopenia is not a known side effect of nivolumab, while preclinical models suggest that checkpoint inhibitors can exacerbate autoimmune disease [7, 8]. We conclude from the present case that immune thrombocytopenia may be induced by treatment with nivolumab.

\section{Disclosure Statement}

The authors did not provide a disclosure statement.

\section{References}

1 Borghaei H, Paz-Ares L, Horn L, Spigel DR, Steins M, Ready NE, Chow LQ, Vokes EE, Felip E, Holgado E: Nivolumab versus docetaxel in advanced nonsquamous non-small cell lung cancer. N Engl J Med 2015; 373:1627-1639.

2 Weber JS, Yang JC, Atkins MB, Disis ML: Toxicities of immunotherapy for the practitioner. J Clin Oncol 2015;33:2092-2099.

3 Gordon IO, Wade T, Chin K, Dickstein J, Gajewski TF: Immune-mediated red cell aplasia after anti-CTLA-4 immunotherapy for metastatic melanoma. Cancer Immunol Immunother 2009;58:1351-1353.
4 Kanameishi S, Otsuka A, Nonomura Y, Fujisawa A, Endo Y, Kabashima K: Idiopathic thrombocytopenic purpura induced by nivolumab in a metastatic melanoma patient with elevated PD-1 expression on B cells. Ann Oncol 2016;27:546-547.

5 Bagley SJ, Kosteva JA, Evans TL, Langer CJ: Immune thrombocytopenia exacerbated by nivolumab in a patient with non-small-cell lung cancer. Cancer Treat Commun 2016;6:20-23.

6 Weide R, Feiten S, Friesenhahn V, Heymanns J, Kleboth K, Thomalla J, van Roye C, Köppler H: Outpatient management of patients with immune thrombocytopenia (ITP) by hematologists 1995-2014. Oncol Res Treat 2016;39:41-44.
7 Wang H-B, Shi F-D, Li H, Chambers BJ, Link H, Ljunggren $\mathrm{H}-\mathrm{G}$ : Anti-CTLA-4 antibody treatment triggers determinant spreading and enhances murine myasthenia gravis. J Immunol 2001;166:6430-6436.

8 Lühder F, Höglund P, Allison JP, Benoist C, Mathis D: Cytotoxic T lymphocyte-associated antigen 4 (CTLA4) regulates the unfolding of autoimmune diabetes. J Exp Med 1998;187:427-432. 